\title{
Leaching of Metals and Metalloids from Hydrothermal Ore Particulates and Their Effects on Marine Phytoplankton
}

\author{
Shigeshi Fuchida, ${ }^{*}+\oplus$ Akiko Yokoyama, ${ }^{\dagger}$ Rina Fukuchi, ${ }^{\dagger}$ Jun-ichiro Ishibashi, ${ }^{\S}$ Shinsuke Kawagucci, ${ }^{\|, \perp}$
} Masanobu Kawachi, ${ }^{\#}$ and Hiroshi Koshikawa ${ }^{\dagger}$

\author{
${ }^{\dagger}$ Marine Environment Section, Center for Regional Environmental Research and ${ }^{\#}$ Biodiversity Resource Conservation Office, Center \\ for Environmental Biology and Ecosystem Studies, National Institute for Environmental Studies (NIES), 16-2 Onogawa, Tsukuba, \\ Ibaraki 305-8506, Japan \\ ${ }^{\ddagger}$ Atmosphere and Ocean Research Institute, The University of Tokyo, 5-1-5 Kashiwanoha, Kashiwa-shi, Chiba 277-8564, Japan \\ ${ }^{\S}$ Department of Earth and Planetary Sciences, Faculty of Science, Kyushu University, 744 Motooka, Nishi-ku, Fukuoka 819-0395, \\ Japan \\ ${ }^{\|}$Department of Subsurface Geobiological Analysis and Research (D-SUGAR) and ${ }^{\perp}$ Research and Development Center for \\ Submarine Resources, Japan Agency for Marine-Earth Science and Technology (JAMSTEC), 2-15 Natsushima-cho, Yokosuka \\ 237-0061, Japan
}

\section{Supporting Information}

\begin{abstract}
Seafloor massive sulfide deposits have attracted much interest as mineral resources. Therefore, the potential environmental impacts of full-scale mining should be considered. In this study, we focused on metal and metalloid contamination that could be triggered by accidental leakage and dispersion of hydrothermal ore particulates from mining vessels into surface seawater. We determined the leaching potential of metals and metalloids from four hydrothermal ores collected from the Okinawa Trough into aerobic seawater and then evaluated the toxic effects of ore leachates on a phytoplankton species, Skeletonema marinoi-dohrnii complex, which is present ubiquitously in the ocean. Large amounts of metals and metalloids were released from the ground hydrothermal ores into seawater within $5 \mathrm{~min}$ under aerobic conditions. The main components of leachates were $\mathrm{Zn}+\mathrm{Pb}, \mathrm{As}+\mathrm{Sb}$, and $\mathrm{Zn}+$ $\mathrm{Cu}$, which were obtained from the $\mathrm{Fe}-\mathrm{Zn}-\mathrm{Pb}$-rich and $\mathrm{Zn}-\mathrm{Pb}$-rich zero-age, Ba-rich, and $\mathrm{Fe}$ rich ores, respectively. The leachates had different chemical compositions from those of the ore. The rapid release and difference in chemical compositions between the leachates and the ores

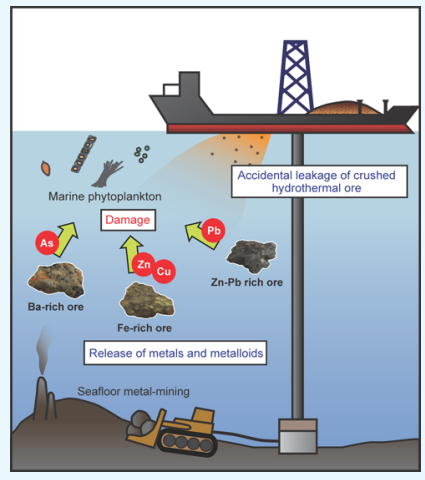
indicated that substances were not directly dissolved from the sulfide-binding mineral phase but from labile phases mainly on the adsorption-desorption interface of the ores under these conditions. All ore leachates inhibited the growth of S. marinoi-dohrnii complex but with different magnitudes of toxic effects. These results indicate that the fine particulate matter of hydrothermal ores is a potential source of toxic contamination that may damage primary production in the ocean. Therefore, we insist on the necessity for the prior evaluation of toxic element leachability from mineral ores into seawater to minimize mining impacts on the surface environment.
\end{abstract}

\section{INTRODUCTION}

Seafloor massive sulfide (SMS) deposits have attracted interest because of their potential as available mineral resources. However, seafloor metal-mining could create new problems in the marine environment and could have serious consequences for marine ecosystems. ${ }^{1,2}$ One of these problems is the potential for metal and metalloid contamination, as metals are easily introduced into ecosystems where they gradually accumulate in the bodies of living organisms. ${ }^{3,4}$

It has been postulated that plumes of fine particulate minerals that arise during mining operations could be a major source of metal and metalloid contamination. ${ }^{2,5}$ Such plumes are generated in the benthic zone as a result of drilling ore minerals and stripping unconsolidated sediment from the seafloor surface and in the epipelagic zone as a result of leakage of crushed ore from mining vessels. Plumes of fine particulate minerals in the epipelagic zone could damage marine phytoplankton communities at the base of the marine food chain. $^{5-8}$ Therefore, the mobility of these metals and metalloids in hydrothermal ores should be evaluated to predict the quantitative impacts of seafloor metal-mining on marine ecosystems.

Various types of ore deposits are present in submarine hydrothermal fields. ${ }^{9-11}$ For example, Halbach et al. (1993) found that the hydrothermal ore in the hydrothermal field of Izena Hole, Okinawa Trough, had various chemical compositions and mineral assemblages, including $\mathrm{Zn}-\mathrm{Pb}$-rich sulfide ore, $\mathrm{Ba}-\mathrm{Zn}-\mathrm{Pb}$ sulfide ore, massive $\mathrm{Zn}-\mathrm{Cu}$-rich sulfide slabs,

Received: April 17, 2017

Accepted: June 9, 2017

Published: July 5, 2017 
Table 1. Chemical Composition of Leachates from Ores (Means \pm Standard Deviation of the Triplicate)

\begin{tabular}{|c|c|c|c|c|c|c|c|c|}
\hline & \multicolumn{2}{|c|}{$\begin{array}{l}\mathrm{Fe}-\mathrm{Zn}-\mathrm{Pb} \text {-rich ore } \\
(\mathrm{HPD} 1313 \mathrm{G} 04)\end{array}$} & \multicolumn{2}{|c|}{ Ba-rich ore (HPD1313G05) } & \multicolumn{2}{|c|}{ Fe-rich ore (HPD1311G06) } & \multicolumn{2}{|c|}{$\begin{array}{l}\mathrm{Zn} \text {-Pb-rich zero-age ore } \\
(\text { HPD1355R04) }\end{array}$} \\
\hline \multicolumn{9}{|c|}{ (a) 5 min Shaking Time } \\
\hline $\mathrm{pH}$ & 4.3 & & 6.8 & & 4.8 & & 6.7 & \\
\hline $\mathrm{Mn}(\mathrm{mM})$ & 0.0108 & \pm 0.0002 & 0.0118 & \pm 0.0009 & 0.17 & \pm 0.02 & 0.118 & \pm 0.005 \\
\hline $\mathrm{Fe}(\mathrm{mM})$ & 4.9 & \pm 0.1 & 0.34 & \pm 0.02 & n.d. & & n.d. & \\
\hline $\mathrm{Cu}(\mathrm{mM})$ & n.d. ${ }^{a}$ & & n.d. & & 0.48 & \pm 0.06 & n.d. & \\
\hline $\mathrm{Zn}(\mathrm{mM})$ & 3.5 & \pm 0.1 & 0.87 & \pm 0.05 & 70 & \pm 9 & 2.2 & \pm 0.1 \\
\hline As $(\mathrm{mM})$ & n.d. & & 0.26 & \pm 0.01 & n.d. & & n.d. & \\
\hline $\mathrm{Cd}(\mathrm{mM})$ & 0.0103 & \pm 0.0003 & n.d. & & 0.19 & \pm 0.02 & 0.0063 & \pm 0.0003 \\
\hline $\mathrm{Sb}(\mathrm{mM})$ & n.d. & & 0.038 & \pm 0.002 & n.d. & & n.d. & \\
\hline $\mathrm{Pb}(\mathrm{mM})$ & 0.224 & \pm 0.006 & n.d. & & n.d. & & 0.094 & \pm 0.006 \\
\hline \multicolumn{9}{|c|}{ (b) $6 \mathrm{~h}$ Shaking Time } \\
\hline $\mathrm{pH}$ & 4.6 & & 6.6 & & 4.9 & & 6.8 & \\
\hline $\mathrm{Mn}(\mathrm{mM})$ & 0.0198 & \pm 0.0003 & 0.0129 & \pm 0.0001 & 0.1640 & \pm 0.0003 & 0.084 & \pm 0.001 \\
\hline $\mathrm{Fe}(\mathrm{mM})$ & 5.62 & \pm 0.02 & 0.100 & \pm 0.002 & n.d. & & n.d. & \\
\hline $\mathrm{Cu}(\mathrm{mM})$ & n.d. & & n.d. & & 1.187 & \pm 0.001 & n.d. & \\
\hline $\mathrm{Zn}(\mathrm{mM})$ & 6.69 & \pm 0.02 & 1.03 & \pm 0.01 & 62 & \pm 1 & 3.67 & \pm 0.01 \\
\hline As $(\mathrm{mM})$ & n.d. & & 0.459 & \pm 0.003 & n.d. & & n.d. & \\
\hline $\mathrm{Cd}(\mathrm{mM})$ & 0.0263 & \pm 0.0002 & n.d. & & 0.188 & \pm 0.001 & 0.01376 & \pm 0.0001 \\
\hline $\mathrm{Sb}(\mathrm{mM})$ & n.d. & & 0.101 & \pm 0.001 & n.d. & & n.d. & \\
\hline $\mathrm{Pb}(\mathrm{mM})$ & 0.231 & \pm 0.001 & n.d. & & n.d. & & 0.089 & \pm 0.002 \\
\hline \multicolumn{9}{|c|}{ (c) $18 \mathrm{~h}$ Shaking Time } \\
\hline $\mathrm{pH}$ & 5.2 & & 6.4 & & 4.9 & & 6.7 & \\
\hline $\mathrm{Mn}(\mathrm{mM})$ & 0.0142 & \pm 0.0001 & 0.0145 & \pm 0.0003 & 0.1576 & \pm 0.0006 & 0.155 & \pm 0.003 \\
\hline $\mathrm{Fe}(\mathrm{mM})$ & 7.6 & \pm 0.2 & 0.135 & \pm 0.009 & n.d. & & n.d. & \\
\hline $\mathrm{Cu}(\mathrm{mM})$ & n.d. & & n.d. & & 1.03 & \pm 0.02 & n.d. & \\
\hline $\mathrm{Zn}(\mathrm{mM})$ & 4.42 & \pm 0.07 & 1.11 & \pm 0.03 & 62.8 & \pm 0.7 & 5.3 & \pm 0.1 \\
\hline As $(\mathrm{mM})$ & n.d. & & 0.38 & \pm 0.01 & n.d. & & n.d. & \\
\hline $\mathrm{Cd}(\mathrm{mM})$ & 0.0201 & \pm 0.0003 & n.d. & & 0.181 & \pm 0.001 & 0.00095 & \pm 0.0001 \\
\hline $\mathrm{Sb}(\mathrm{mM})$ & n.d. & & 0.096 & \pm 0.006 & n.d. & & n.d. & \\
\hline $\mathrm{Pb}(\mathrm{mM})$ & 0.223 & \pm 0.001 & n.d. & & n.d. & & 0.103 & \pm 0.001 \\
\hline
\end{tabular}

Fe-rich replacement ore, and $\mathrm{Zn}-\mathrm{Pb}$-rich impregnation ore. 9 These chemical compositions and mineral assemblages depend on the geological setting and fluid chemistry. The chemical compositions of leachates are expected to differ among different types of hydrothermal ores.

Simpson et al. (2007) studied the leachability of metals and metalloids from hydrothermal mineral ores collected from both active and inactive vent chimneys in the East Manus Basin hydrothermal field (Papua New Guinea) as part of the Solwara 1 project. $^{8}$ They observed that large amounts of $\mathrm{Mn}, \mathrm{Cu}, \mathrm{Zn}$, and $\mathrm{As}$ and small amounts of $\mathrm{Ni}, \mathrm{Ag}, \mathrm{Cd}$, and $\mathrm{Pb}$ were rapidly released into oxic seawater from these mineral ore samples. However, they did not take into account the relationship between the chemical composition of the leachates and those of the hydrothermal ores.

In this study, we investigated the leachability of metals and metalloids from fine particulates of various hydrothermal ores collected in the Okinawa Trough. These ore samples had different chemical compositions and mineral assemblages. As well as the potential for leaching, we also determined the toxicity of the leachates to a marine phytoplankton, Skeletonema marinoi-dohrnii complex (formerly classified into Skeletonema costatum, $^{12,13}$ one of the ecotoxicological standard test organisms used to evaluate seawater quality). ${ }^{7,14}$ On the basis of our results, we discuss the possibility of metal and metalloid contamination through the dispersion of hydrothermal ores into the surface layer and their potential effects on marine phytoplankton primary production. These are important potential issues related to seafloor metal-mining.

\section{RESULTS AND DISCUSSION}

2.1. Release of Metals and Metalloids from Mineral Ore Particulates. The leachates contained large amounts of $\mathrm{Mn}, \mathrm{Fe}, \mathrm{Cu}, \mathrm{Zn}, \mathrm{As}, \mathrm{Cd}, \mathrm{Sb}$, and $\mathrm{Pb}$ (Table 1). The leachates from all ore samples commonly contained $\mathrm{Zn}$ and $\mathrm{Mn}$, whereas $\mathrm{Cd}$ was detected from all leachates except that from the Ba-rich ore (HPD1313G05). The Fe-Zn-Pb-rich (HPD1313G04) and the $\mathrm{Zn}-\mathrm{Pb}$-rich zero-age (HPD1355R04) ores released $\mathrm{Pb}$. Only the Ba-rich ore released As and Sb.

Among all leached metals and metalloids, $\mathrm{Zn}$ showed the highest concentrations in most of the leachates produced under these experimental conditions. The $\mathrm{Zn}$ concentration was higher in the leachate from the Fe-rich ore (HPD1311G06) than in the leachates from the $\mathrm{Fe}-\mathrm{Zn}-\mathrm{Pb}$-rich, Ba-rich, and $\mathrm{Zn}-\mathrm{Pb}$-rich ores.

In hydrothermal ores, $\mathrm{Zn}$ is generally present as a monosulfide mineral, sphalerite. ${ }^{15}$ Small amounts of $\mathrm{Mn}$ and $\mathrm{Cd}$ are present in sphalerite as impurities; ${ }^{16}$ consequently, the amounts of $\mathrm{Mn}$ and $\mathrm{Cd}$ in the ores were positively correlated with that of $\mathrm{Zn}$ (Figure S1a). As expected, the concentrations of $\mathrm{Mn}$ and $\mathrm{Cd}$ in the leachates were also positively correlated with that of $\mathrm{Zn}$ (Figure S1b). These findings indicate that sphalerite in the ores was the main source of $\mathrm{Zn}$ and also of $\mathrm{Mn}$ and $\mathrm{Cd}$. 
Figure 1 shows the leaching ratios of each metal and metalloid from the solid ore samples. The leaching ratios of $\mathrm{Mn}$

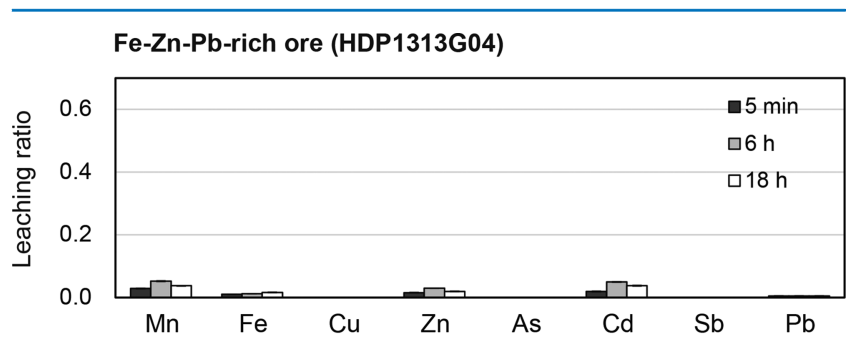

Ba-rich ore (HDP1313G05)

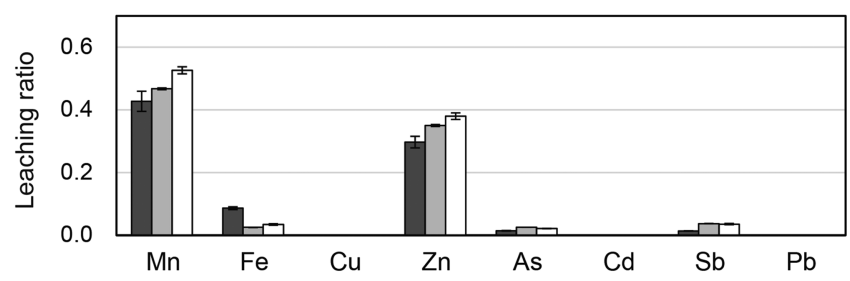

Fe-rich ore (HDP1311G06)

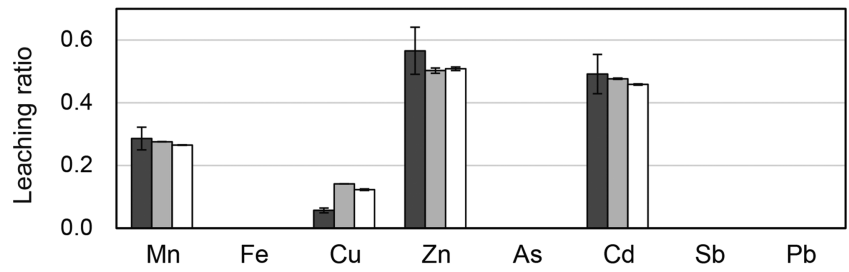

$\mathrm{Zn}$-Pb-rich zero-age ore (HDP1355R04)

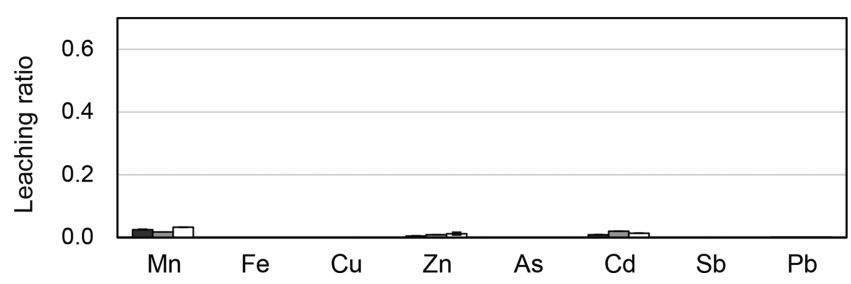

Figure 1. Leaching ratios of metals and metalloids from solid ore samples. and $\mathrm{Zn}$ from Ba-rich and Fe-rich ores were significantly high, even though sphalerite was not found in Ba-rich and Fe-rich ores (Table 2). However, the leaching ratios of $\mathrm{Mn}, \mathrm{Zn}$, and $\mathrm{Cd}$ were significantly low in the leachates from the $\mathrm{Zn}-\mathrm{Pb}$-rich and the $\mathrm{Fe}-\mathrm{Zn}-\mathrm{Pb}$-rich zero-age ores, which contained large proportions of sphalerite. Such different leaching ratios from different types of ores might imply that metal leaching under these experimental conditions was not because of direct dissolution from sphalerite. The other major minerals in the ore samples such as pyrite (an Fe sulfide mineral) in the Fe-rich ore and chalcopyrite (a $\mathrm{Cu}-\mathrm{Fe}$ sulfide mineral) in the $\mathrm{Zn}-\mathrm{Pb}$ rich zero-age ore showed similar leaching characteristics. We did not detect $\mathrm{Fe}$ in the leachate from the Fe-rich ore containing pyrite, nor did we detect $\mathrm{Cu}$ from the $\mathrm{Zn}-\mathrm{Pb}$-rich zero-age ore containing chalcopyrite.

In general, sulfide minerals such as sphalerite, pyrite, and chalcopyrite frequently found in hydrothermal ores react with water and oxygen and release the metal ion and sulfate, as per the following equation ${ }^{17}$ (where $\mathrm{M}$ is a divalent metal)

$$
\mathrm{MS}+2 \mathrm{H}_{2} \mathrm{O}+\mathrm{O}_{2} \rightarrow \mathrm{M}^{2+}+\mathrm{SO}_{4}^{2-}+4 \mathrm{H}^{+}
$$

This oxidation reaction could be accelerated under aerobic water conditions, but the reaction rates are very slow. ${ }^{18,19}$ The low leaching ratios from our sulfide mineral samples also indicate that the rate of such reactions is very slow. Consequently, direct dissolution of these metals from sulfide minerals would make only a minor contribution to the dissolved metals in the leachates.

Desorption is another mechanism for the intense release of metals and metalloids from ores. Desorption releases metals from sulfide minerals significantly faster than direct dissolution because the binding strength of metals in adsorption states is significantly weaker than that of metals in sulfide mineral states. $^{20,21}$ Under our experimental conditions, large amounts of metals and metalloids were released within 5 min of shaking (Table 1a), and their concentrations in leachates showed little change after 6 or $18 \mathrm{~h}$ of shaking. These results indicated that desorption greatly contributed to the release of metals from the ores into the solution.

In our experiment, the $\mathrm{pH}$ values of leachates from the $\mathrm{Fe}-$ $\mathrm{Zn}-\mathrm{Pb}$-rich, the Ba-rich, the Fe-rich, and the $\mathrm{Zn}-\mathrm{Pb}$-rich zeroage ores decreased to $4.3,6.8,4.8$, and 6.7 , respectively, after shaking for $5 \mathrm{~min}$. Such rapid decreases in $\mathrm{pH}$ suggest that

Table 2. Mineral Assemblage of Ore Samples ${ }^{a}$

\begin{tabular}{|c|c|c|c|c|}
\hline & HPD1313G04 & HPD1313G05 & HPD1311G06 & HPD1355R04 \\
\hline sphalerite & $* * *$ & & & $* * *$ \\
\hline galena & $* *$ & & & $* *$ \\
\hline anglesite & $* *$ & & & $* *$ \\
\hline anhydrite & & & & $* *$ \\
\hline cubanite & & & & $*$ \\
\hline chalcopyrite & & & & $*$ \\
\hline marcasite & & & & $*$ \\
\hline wurtzite & & & & $*$ \\
\hline stannite & & & & $*$ \\
\hline pyrite & & & $* * *$ & \\
\hline tridimite & & & $*$ & \\
\hline bianchite & & & $*$ & \\
\hline barite & & $* * *$ & & \\
\hline realgar & & $*$ & & \\
\hline
\end{tabular}




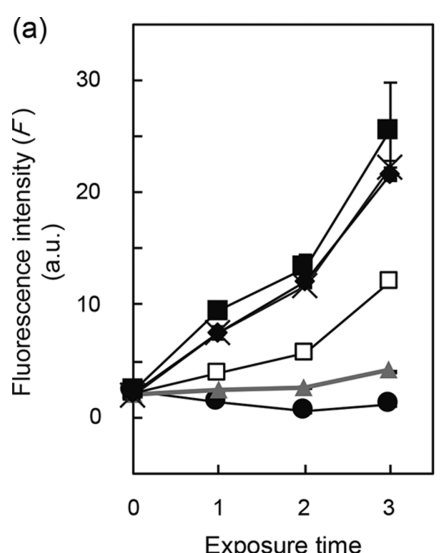

(day)

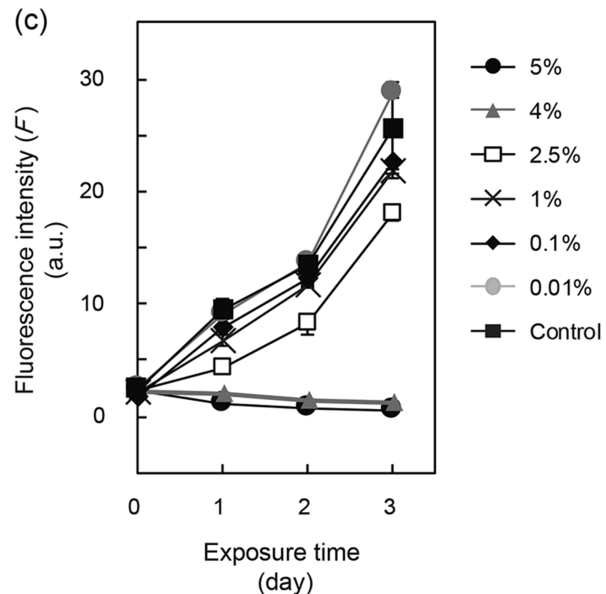

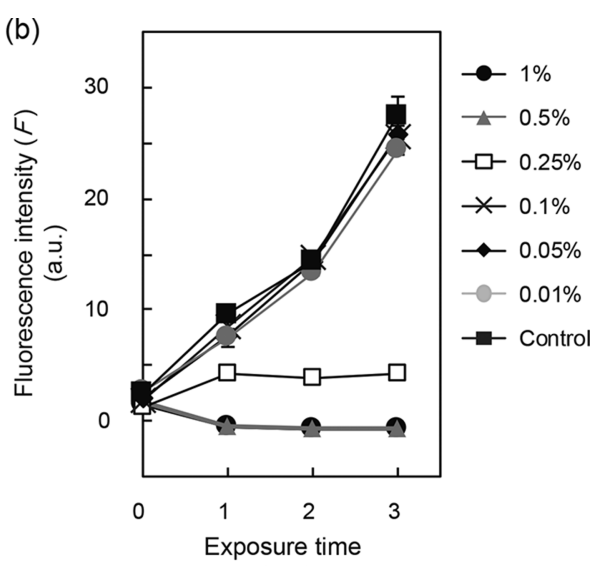

(day)

Figure 2. Effect of different leachate concentrations on the growth of Skeletonema marinoi-dohrnii complex. (a) Ba-rich ore (HPD1313G05), (b) Ferich ore (HPD1311G06), and (c) Zn-Pb-rich zero-age ore (HPD1355R04).

sulfide minerals had been oxidized, sulfuric acids had formed, and metals had been protonated on the surface of ores before our experiment, that is, during sample storage (deprotonation of weak acids, e.g., $\mathrm{H}_{2} \mathrm{~S}$ and $\mathrm{H}_{2} \mathrm{SO}_{3}$, and hydrolysis of heavy metal ions, e.g., $\mathrm{Fe}^{3+}$ might also lead to decreased $\mathrm{pH}$ ). The protonated metal ions would be adsorbed onto deoxidized sulfides $^{22}$ and other secondary minerals such as hydroxide mineral surfaces ${ }^{23,24}$ by the formation of weak chemical bonds.

Adsorbed metal ions are easily desorbed via an ion exchange reaction involving hydrogen ions, as follows ${ }^{17}$ (where $\equiv$ indicates the mineral surface)

$$
\equiv \mathrm{MS}+2 \mathrm{H}^{+} \rightarrow \equiv \mathrm{SH}_{2}+\mathrm{M}^{2+}
$$

Studies on the ion exchange reaction on the surface of hydrous $\mathrm{PbS}$ and $\mathrm{ZnS}$ have concluded that significant amounts of $\mathrm{Pb}$ and $\mathrm{Zn}$ can be released into solution via this reaction. ${ }^{25,26}$ The metal sulfide surface exhibits acid/base properties after hydration, and the metal ion is replaced by a highly reactive hydrogen ion. The result of this reaction is that metals adsorbed onto the mineral surface are easily and rapidly released (desorbed) into the solution. The ion exchange reaction occurs at $\mathrm{pH}$ values between 4 and $7 .^{17}$ The $\mathrm{pH}$ values of leachates in this study were 4.3-6.8. Therefore, we conclude that the process of ion exchange contributed to the rapid release of metals from the ores.

On the basis of the experimental evidence and the reactions shown above, most of the metals and metalloids in the leachates could not be directly dissolved from sulfide minerals in the ore during the short shaking time but would have been released via desorption reactions such as ion exchange.

2.2. Effect of Ore Leachates on Marine Phytoplankton. Figure 2 shows the changes in the fluorescence of $S$. marinoi-dohrnii complex over time in different treatments. In this experiment, the algae were grown in multiwell plates. The fluorescence in the control wells showed relatively stable increases over time, reflecting the increase in cell density. Compared with control wells, those containing leachates at a concentration of less than $0.1 \%$ showed no obvious inhibition effects on diatom growth. We constructed dose-inhibition curves using the relative growth rate, which was calculated by normalizing the raw growth rates of each exposure well to that of the control well (Figure 3). In wells containing leachates at concentrations $>0.1 \%$, the inhibition effects were demonstrable (Figures 2 and 3). In some cases (medium containing 10\% Barich, 0.5 and $1 \% \mathrm{Fe}$-rich, and $4 \% \mathrm{Zn}-\mathrm{Pb}$-rich zero-age ores), the fluorescence intensities of the wells gradually and almost monotonously decreased during the experiment, implying that there was strong growth inhibition and either cell death or decomposition of the chlorophyll pigments (Figure 2). We note here that the relative growth rates were shown as zero in Figure 3 when negative changes in the fluorescence were recorded (Figure 2).

The leachate from the Fe-rich ore was the most toxic to $S$. marinoi-dohrnii complex (Figure 3) and was lethal at concentrations below $1 \%$. The leachate from the $\mathrm{Zn}-\mathrm{Pb}$-rich 


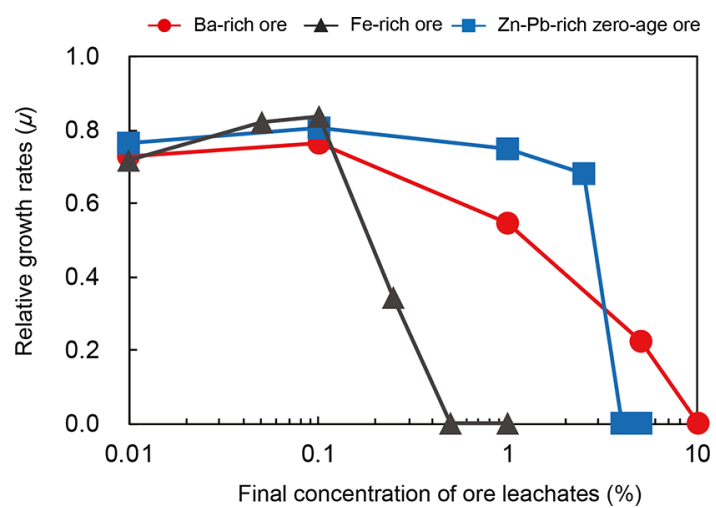

Figure 3. Relative growth rates $(\mu)$ of Skeletonema marinoi-dohrnii complex after addition of ore leachates. Leachate concentrations: 0.01, $0.1,1,5$, and $10 \%$ for Ba-rich ore (HPD1313G05); 0.01, 0.05, 0.1, $0.25,0.5$, and $1 \%$ for Fe-rich ore (HPD1311G06); and 0.01, 0.1, 1, 2.5, 4 , and $5 \%$ for $\mathrm{Zn}-\mathrm{Pb}$-rich zero-age ore (HPD1355R04).

zero-age ore showed medium toxicity, but its toxicity increased markedly at concentrations higher than $4 \%$. The leachate from Ba-rich ores also inhibited the growth of $S$. marinoi-dohrnii complex, and its inhibitory effect grew stronger with increasing concentrations.

Metals and metalloids in the leachates would contribute to the growth inhibition of $S$. marinoi-dohrnii complex, although the specific toxicants inhibiting growth have not been identified in this study. The half-maximal inhibition concentrations of metals and metalloids on Skeletonema costatum reported in previous studies are as follows: $\mathrm{Zn}, 2.2 \mu \mathrm{M} ; \mathrm{Cd}, 1.2 \mu \mathrm{M} ; \mathrm{Pb}$, $0.094 \mu \mathrm{M} ;{ }^{27} \mathrm{Cu}, 0.42 \mu \mathrm{M} ;{ }^{28}$ As, $0.17 \mu \mathrm{M}^{29}$ and $\mathrm{Sb},>34 \mu \mathrm{M}^{30}$ The results of these studies indicated that $\mathrm{Pb}, \mathrm{Cu}$, and As are more toxic to S.costatum than $\mathrm{Zn}, \mathrm{Cd}$, and $\mathrm{Sb}$. In the present study, the cell death for S. marinoi-dohrnii complex occurred when the following toxic elements were present at high concentrations in the culture medium: $\mathrm{Pb}(35.4 \mu \mathrm{M})$ in the leachate from the $\mathrm{Zn}-\mathrm{Pb}$-rich zero-age ores, $\mathrm{Cu}(5.9 \mu \mathrm{M})$ in the leachate from the Fe-rich ores, and As $(45.9 \mu \mathrm{M})$ in the leachate from the Ba-rich ores. Therefore, these elements that leached from the ores inhibit the growth of S. marinoi-dohrnii complex.

Addition of the leachates from $\mathrm{Fe}$-rich and $\mathrm{Zn}-\mathrm{Pb}$-rich ores to culture media (Daigo IMK medium) resulted in a decrease in $\mathrm{pH}$ from 8.5 to 7.1 and 7.7 , respectively. Taraldsvik and Myklestad (2000) determined the effects of $\mathrm{pH}$ on the growth rate of $S$. costatum and found no significant difference in the growth rates at $\mathrm{pH}$ values $6.5-8.5^{39}$ In this study, therefore, the growth of $S$. marinoi-dohrnii complex was more likely inhibited by the metals and metalloids in the leachates than by changes in the $\mathrm{pH}$ of the growth medium.

The present study was conducted with S. marinoi-dohrnii complex, one of the suitable phytoplanktons as an ecotoxicological model organism, to evaluate the toxic effects of ore leachates. It should be noted that similar experimental surveys targeting representative species in open oceans might be necessary to resolve ecological impact on the primary production and biodiversity for future studies.

2.3. Importance for Environmental Impact Assessment of Seafloor Metal-Mining Using Leaching Test. Evaluations of the leachability of metals and metalloids from ore particulates into seawater and their toxicity to marine organisms are important to design practical mining plans and processes that minimize the impacts of seafloor metal-mining on marine environments.

Recently, Simpson and Spadaro (2016) have also suggested the necessity to evaluate the potential toxicity of leachates from sulfide minerals. They demonstrated that $\mathrm{Zn}, \mathrm{Pb}$, and $\mathrm{Cu}$ were released from the reference materials of sphalerite, galena, and chalcopyrite particulates, respectively, and showed that these metals in ionic forms in solution were toxic to marine benthic invertebrates (bivalve and juvenile amphipods) commonly found on the seafloor of deep oceans. ${ }^{2}$

Our study demonstrated the potential leachability of metals and metalloids not from reference materials but from natural hydrothermal ores, and their toxicity to marine phytoplankton commonly found in the surface environment. A crucial finding in this study is that the chemical composition and concentrations of the leachates cannot be easily predicted by those of the ores. Therefore, bulk analysis of ores is insufficient. Instead, leaching tests are essential to predict the potential release of metals and metalloids from hydrothermal ores for seafloor metal-mining, as is the case for land-mining wastes and contaminated sediments. ${ }^{32,33}$

Metal and metalloid sulfide minerals are under anoxic conditions when hydrothermal ores are left undisturbed on the seafloor. However, the sulfide minerals on the surface of the hydrothermal ore samples used in this study would have been oxidized by air, and metals and metalloids would have transformed into labile states during sample storage. This is one reason why large amounts of metals and metalloids were released into the leachate solutions.

In the SMS-mining model proposed by several contractors such as Nautilus Minerals Ltd. and Japan Oil, Gas and Metals National Corporation (JOGMEC), mineral ores are crushed using a seafloor mining tool, raised from the seafloor through a riser pipe, and then stored on a mining support vessel. ${ }^{34-36} \mathrm{On}$ the vessel, the sulfide minerals will gradually be oxidized by exposure to air and rain water. Their transformation into leachable phases during storage means that they will release toxic metals and metalloids if they are released into seawater.

There may be low dissolution of metals and metalloids from anoxic (fresh) ores than from oxidized ores; however, the evaluation of leaching potential from oxidized hydrothermal ores is important for thorough marine environmental impact assessments. Therefore, our results provide reference values for the maximum amounts of metals and metalloids that might be leached when hydrothermal minerals are oxidized and accidentally spilled into the surface environment.

\section{CONCLUSIONS}

We showed that metals and metalloids were rapidly released from oxidized hydrothermal ores with different leachabilities. It is natural that different ores have different leachabilities. However, our results also showed that the compositions of the leachates did not completely reflect the chemical compositions and concentrations of the ores and that the different leachates had different degrees of toxicity to the test phytoplankton. These results suggest that analyses of the bulk chemical composition of ores will not provide enough information to predict the potential release of metal and metalloids in the surface layer. For more accurate predictions, ores should be subjected to leaching tests as well as chemical analyses, as performed in this study.

The possible environmental risks of full-scale seafloor mining and the measures to mitigate these risks are still under 
discussion. One environmental risk is the metal contamination and its adverse effects on the marine ecosystem. The results of our study will be useful for future predictions of environmental impacts of mining on the surface environment.

\section{MATERIALS AND METHODS}

4.1. Hydrothermal Mineral Samples. The four hydrothermal ore samples (HPD1313G04, HDP1313G05, HDP1311G06, and HDP1355R04) used in this study were provided by the Japan Agency for Marine-Earth Science and Technology (JAMSTEC). These samples were collected from the hydrothermal vent fields at the Izena Hole (NT11-15 cruise, August 2011) and the Iheya North Knoll (NT12-06 cruise, March 2012) by the Hyper Dolphin 3K, a remotely operated vessel owned by JAMSTEC (Figure 4 and Table S1).

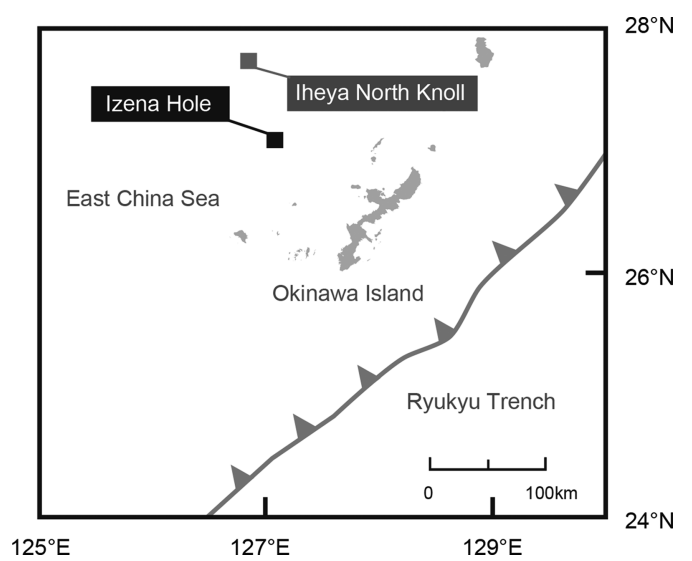

Figure 4. Sampling sites at Izena Hole and Iheya North Knoll, Okinawa Trough.

Photographs of the collected hydrothermal ores are shown in Figure 5. The occurrence of sulfide deposits associated with high-temperature fluid vents has been reported in other studies. $^{11,37-40}$ The mineral assemblages of the ores (Table (a)

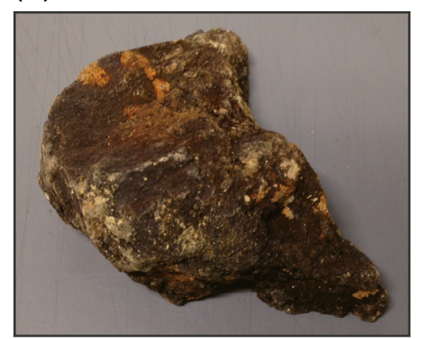

(c)

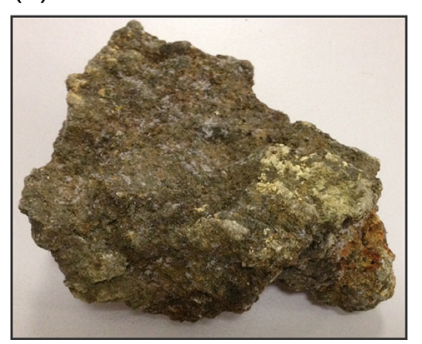

(b)

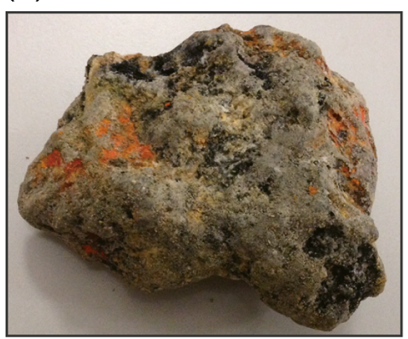

(d)

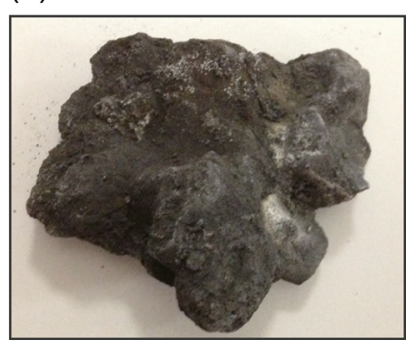

Figure 5. Ore samples used for leaching experiment. (a) HPD1313G04, (b) HPD1313G05, (c) HPD1311G06, and (d) HPD1355R04.
2) were determined by X-ray diffraction (XRD, Rigaku Geigerflex RAD-IA, Tokyo, Japan) using Ni-filtered monochromatic $\mathrm{Cu} \mathrm{K} \alpha$ radiation $(\lambda=1.5418 \AA$ ) with $2 \theta$ angle between $5^{\circ}$ and $70^{\circ}$. Metal and metalloid compositions of the ores (Table 3 ) were determined using an inductively coupled

Table 3. Chemical Composition of Ore Samples ( $\mathrm{mmol} / \mathrm{kg}$ )

\begin{tabular}{lcccc} 
& HPD1313G04 & HPD1313G05 & HPD1311G06 & HPD1355R04 \\
$\mathrm{Mn}$ & 3.8 & 0.28 & 5.9 & 47 \\
$\mathrm{Fe}$ & 4700 & 39 & 5400 & 1600 \\
$\mathrm{Cu}$ & 37 & 0.67 & 84 & 490 \\
$\mathrm{Zn}$ & 2300 & 29 & 1200 & 4300 \\
$\mathrm{As}$ & 1.9 & 179 & 71 & 16 \\
$\mathrm{Cd}$ & 5.3 & 0.029 & 3.9 & 6.8 \\
$\mathrm{Sb}$ & 0.72 & 27 & 1.8 & 3.4 \\
$\mathrm{~Pb}$ & 460 & 0.94 & 1.9 & 510 \\
\hline
\end{tabular}

plasma-mass spectrometry (ICP-MS, 8800 ICP-QQQ Agilent Technologies, Inc., CA, USA). For these analyses, ore samples $\left(10-20 \mathrm{mg}\right.$ ) were dissolved in $\mathrm{HF} / \mathrm{HCl} / \mathrm{HNO}_{3}(1 / 1 / 2, \mathrm{v} / \mathrm{v} / \mathrm{v})$ at $25{ }^{\circ} \mathrm{C}$ overnight and then dried on a hot plate at $80-100$ ${ }^{\circ} \mathrm{C} .{ }^{41,42}$ Metals and metalloids in a low oxidation state are readily oxidized by $\mathrm{HNO}_{3}$ and $\mathrm{HClO}$. The reactants were mixed with aqua regia and dried on a hot plate at $80-100{ }^{\circ} \mathrm{C}$. After cooling to $25{ }^{\circ} \mathrm{C}$, the residue was dissolved in $\mathrm{HNO}_{3}$ and diluted with ultrapure water before the ICP-MS analysis. Duplicate ore samples were digested and analyzed to confirm the reproducibility, although reference material of seafloor hydrothermal ores was not analyzed in this study.

Sample HPD1313G04 consisted of Fe $(4700 \mathrm{mmol} / \mathrm{kg}), \mathrm{Zn}$ $(2300 \mathrm{mmol} / \mathrm{kg}), \mathrm{Pb}(460 \mathrm{mmol} / \mathrm{kg})$, and $\mathrm{Cu}(37 \mathrm{mmol} / \mathrm{kg})$ and mainly comprised sulfide minerals, such as sphalerite and galena. Sample HPD1355R04 consisted of various sulfide minerals (sphalerite, galena, chalcopyrite, wurtzite, and marcasite) and sulfate minerals (anhydrite and anglesite). Sample HPD1355R04 was a piece of an infant chimney ("zeroage") and mainly consisted of Ca-sulfate minerals. ${ }^{42}$ Sample HPD1355R04 contained $\mathrm{Zn}(4300 \mathrm{mmol} / \mathrm{kg}), \quad \mathrm{Fe}(1600$ $\mathrm{mmol} / \mathrm{kg}), \mathrm{Pb}(510 \mathrm{mmol} / \mathrm{kg})$, and $\mathrm{Cu}(490 \mathrm{mmol} / \mathrm{kg})$. Pyrite was the dominant mineral in sample HPD1311G06. Sample HPD1311G06 contained significant amounts of $\mathrm{Fe}$ (5400 $\mathrm{mmol} / \mathrm{kg})$ and $\mathrm{Zn}(1200 \mathrm{mmol} / \mathrm{kg})$, with small amounts of $\mathrm{Cu}$ (84 mmol/ kg), As (71 mmol/kg), and $\mathrm{Pb}(1.9 \mathrm{mmol} / \mathrm{kg})$. Barite was the most abundant mineral in sample HPD1313G05. Compared with the other samples, sample HPD1313G05 contained smaller amounts of Fe (39 mmol $/ \mathrm{kg}), \mathrm{Zn} \mathrm{(29}$ $\mathrm{mmol} / \mathrm{kg}), \mathrm{Cu}(0.67 \mathrm{mmol} / \mathrm{kg})$, and $\mathrm{Pb}(0.94 \mathrm{mmol} / \mathrm{kg})$ but high concentrations of As $(179 \mathrm{mmol} / \mathrm{kg})$ and $\mathrm{Sb}(27 \mathrm{mmol} /$ $\mathrm{kg})$.

On the basis of the chemical compositions and mineral assemblages of the ores, samples HPD $1313 \mathrm{G} 04$, HPD1313G05, HPD1311G06, and HPD1355R04 were designated as $\mathrm{Fe}-\mathrm{Zn}-\mathrm{Pb}$-rich, Ba-rich, Fe-rich, and $\mathrm{Zn}-\mathrm{Pb}$-rich ores, respectively, in this study.

4.2. Leaching Experiments. Each ore sample was crushed and powdered manually before leaching experiments using tungsten carbide and agate mortars and was sieved through 1/ $16 \mathrm{~mm}$ mesh. Approximately $3 \mathrm{~g}$ of the powdered sample was stirred into $30 \mathrm{~mL}$ of artificial seawater (Daigo's SP, Nihon Pharmaceutical Co. Ltd., Tokyo, Japan; $\mathrm{pH}=8.2$; dissolved oxygen $=5.7 \mathrm{mg} / \mathrm{L})$ in an acid-cleaned polypropylene centrifuge tube $(50 \mathrm{~mL})$ under dark condition, and then the 
tube was reciprocally shaken at $200 \mathrm{rpm}$ per min at $25^{\circ} \mathrm{C}$ for 5 $\min , 6 \mathrm{~h}$, or $18 \mathrm{~h}$. The shaking for $6 \mathrm{~h}$ is prescribed by the Japanese Ministry for the Environment as the standard method. The shaking for $5 \mathrm{~min}$ and $18 \mathrm{~h}$ are recommended by the United States Environmental Protection Agency and the United States Geological Survey, respectively. The chemical components of the artificial seawater are shown in Table S2. Samples were prepared in triplicate for each combination. After shaking, the solid phase was separated by centrifugation $(1880 \mathrm{~g}$ for $10 \mathrm{~min}$ ) and collected by filtration through a polyvinylidene difluoride membrane filter $(0.45 \mu \mathrm{m})$. The $\mathrm{pH}$ of the leachates was measured using a $\mathrm{pH}$ meter (Horiba D-75, Horiba, Ltd., Kyoto, Japan) calibrated at $\mathrm{pH}$ values of 4.01 and 6.86. A portion of the leachate was acidified with $\mathrm{HNO}_{3}$ and preserved in a polypropylene tube. Metals and metalloids present at detectable levels in the leachates (i.e., $\mathrm{Mn}, \mathrm{Fe}, \mathrm{Cu}, \mathrm{Zn}, \mathrm{As}, \mathrm{Cd}$, $\mathrm{Sb}$, and $\mathrm{Pb}$ ) were selected after screening using ICP-atomic emission spectroscopy (ICAP-75, Nippon Jarrell-Ash Co. Ltd., Kyoto, Japan) and were quantified using ICP-MS. The limit of detection (nM) was calculated using the regression equation that fit the standard calibration curve: ${ }^{43} 0.28$ for $\mathrm{Mn}, 1.3$ for $\mathrm{Fe}$, 0.12 for $\mathrm{Cu}, 2.4$ for $\mathrm{Zn}, 0.58$ for As, 0.027 for $\mathrm{Cd}, 0.084$ for $\mathrm{Sb}$, and 0.027 for $\mathrm{Pb}$.

4.3. Phytoplankton Growth Inhibition Assay. Growth inhibition assays of the three leachates prepared from HPD1313G05, HPD1311G06, and HPD1355R04 were conducted using an axenic marine diatom, S. marinoi-dohrnii complex NIES-324 (formerly classified into S. costatum) ${ }^{12,13}$ obtained from the Microbial Culture Collection at the National Institute of Environmental Studies (http://mcc.nies.go.jp). Skeletonema costatum is one of the most popular algal test organisms for the toxicity tests of contaminants in seawater. The test organism was maintained and precultured before growth inhibition tests in the Daigo IMK medium (Nihon Pharmaceutical Co., Ltd., Tokyo, Japan) prepared with $90 \%$ natural seawater and $10 \%$ distilled water, under a white fluorescent light with a photon flux density of $70 \mu \mathrm{mol}$ photons $\mathrm{m}^{-2} \mathrm{~s}^{-1}$ and a $12 \mathrm{~h} / 12 \mathrm{~h}$ light/dark photoperiod at $20{ }^{\circ} \mathrm{C}$. The precultured cell suspension in the logarithmic growth phase was diluted with a fresh culture medium (1:19), and then $0.9 \mathrm{~mL}$ aliquots were transferred into Falcon 48-well microplates (Corning, Inc., NY, USA). The initial fluorescence of the cell suspension in each well was determined using a microplate reader (MTP-810 Lab, Corona Electric Co. Ltd., Ibaraki, Japan) (excitation, $430 \mathrm{~nm}$; emission, $680 \mathrm{~nm}$ ) as a proxy of the chlorophyll $a$ content and/or cell concentration on Day 0 . Subsequently, each cell suspension in duplicate wells was exposed to one of the three leachates at multiple concentrations ranging from 0.01 to $10 \%$. Six control wells were also prepared (cell suspension but no leachate). The microplates were incubated for 3 days under the culture conditions described above. Daily changes in fluorescence intensities were determined to calculate the growth rate $(\mu)$ of the test organism in each well, using the following equation

$$
\mu=\left(\ln F_{n}-\ln F_{0}\right) /\left(t_{n}-t_{0}\right)
$$

where $F_{n}$ and $F_{0}$ are the fluorescence intensities on Day $n$ and Day 0 , respectively, and $t_{n}$ and $t_{0}$ are the number of days. We note here that the background fluorescence emitted from the polystyrene microplate and the media solution was removed by subtracting blank measurements (from wells containing only medium) before calculating $F_{n}$ and $F_{0}$.

\section{ASSOCIATED CONTENT}

\section{Supporting Information}

The Supporting Information is available free of charge on the ACS Publications website at DOI: 10.1021/acsomega.7b00081.

Amounts of $\mathrm{Zn}-\mathrm{Cd}$ and $\mathrm{Zn}-\mathrm{Mn}$ in (a) ores ( $\mathrm{mmol} / \mathrm{kg}$ ) and (b) leachates (mM), sampling locations of the hydrothermal ores, and chemical composition of artificial seawater (Daigo's SP, Nihon Pharmaceutical Co. Ltd) (PDF)

\section{AUTHOR INFORMATION}

\section{Corresponding Author}

*E-mail: fuchida.shigeshi@nies.go.jp. Phone: +81-2-9850-2883.

Fax: +81-2-9850-2569 (S.F.).

ORCID

Shigeshi Fuchida: 0000-0003-1655-4887

Notes

The authors declare no competing financial interest.

\section{ACKNOWLEDGMENTS}

We thank K. Fujimoto of Tokyo Gakugei University for performing the XRD analysis. This study was financially supported by the Cross Ministerial Strategic Innovation Promotion Program (SIP), "Next-Generation Technology for Ocean Resource Exploration" (funding agency: JAMSTEC).

\section{REFERENCES}

(1) Nakajima, R.; Yamamoto, H.; Kawagucci, S.; Takaya, Y.; Nozaki, T.; Chen, C.; Fujikura, K.; Miwa, T.; Takai, K. Post-drilling changes in seabed landscape and megabenthos in a deep-sea hydrothermal system, the Iheya North field, Okinawa Trough. PLoS One 2015, 10, No. e0123095.

(2) Simpson, S. L.; Spadaro, D. A. Bioavailability and Chronic Toxicity of Metal Sulfide Minerals to Benthic Marine Invertebrates: Implications for Deep Sea Exploration, Mining and Tailings Disposal. Environ. Sci. Technol. 2016, 50, 4061-4070.

(3) Simpson, S. L.; Apte, S. C.; Batley, G. E. Effect of short-term resuspension events on trace metal speciation in polluted anoxic sediments. Environ. Sci. Technol. 1998, 32, 620-625.

(4) Eggleton, J.; Thomas, K. V. A review of factors affecting the release and bioavailability of contaminants during sediment disturbance events. Environ. Int. 2004, 30, 973-980.

(5) Ahnert, A.; Borowski, C. Environmental risk assessment of anthropogenic activity in the deep-sea. J. Aquat. Ecosyst. Stress Recovery 2000, 7, 299-315.

(6) Nayar, S.; Goh, B. P. L.; Chou, L. M. Environmental impact of heavy metals from dredged and resuspended sediments on phytoplankton and bacteria assessed in in situ mesocosms. Ecotoxicol. Environ. Saf. 2004, 59, 349-369.

(7) Satoh, A.; Vudikaria, L. Q.; Kurano, N.; Miyachi, S. Evaluation of the sensitivity of marine microalgal strains to the heavy metals, $\mathrm{Cu}, \mathrm{As}$, $\mathrm{Sb}, \mathrm{Pb}$ and $\mathrm{Cd}$. Environ. Int. 2005, 31, 713-722.

(8) Simpson, S.; Angel, B.; Hamilton, I.; Spadaro, D.; Binet, M. Water and sediment characterisation and toxicity assessment for the Solwara 1 project. In Environmental Impact Statement; Natural Minerals Inc.: Australia; Appendices 4-7, September 2007; Vol. B.

(9) Halbach, P.; Pracejus, B.; Maerten, A. Geology and mineralogy of massive sulfide ores from the central Okinawa Trough, Japan. Econ. Geol. 1993, 88, 2210-2225.

(10) Ishibashi, J.-I.; Noguchi, T.; Toki, T.; Miyabe, S.; Yamagami, S.; Onishi, Y.; Yamanaka, T.; Yokoyama, Y.; Omori, E.; Takahashi, Y.; Hatada, K.; Nakaguchi, Y.; Yoshizaki, M.; Konno, U.; Shibuya, T.; Takai, K.; Inagaki, F.; Kawagucci, S. Diversity of fluid geochemistry affected by processes during fluid upwelling in active hydrothermal 
fields in the Izena Hole, the middle Okinawa Trough back-arc basin. Geochem. J. 2014, 48, 357-369.

(11) Ishibashi, J.-i.; Ikegami, F.; Tsuji, T.; Urabe, T. Hydrothermal activity in the Okinawa Trough back-arc basin: geological background and hydrothermal mineralization. In Subseafloor Biosphere Linked to Hydrothermal Systems: TAIGA Concept; Ishibashi, J.-i., Okino, K., Sunamura, M., Eds.; Springer: Japan, 2015; pp 337-359.

(12) Ellegaard, M.; Godhe, A.; Härnström, K.; McQuoid, M. The species concept in a marine diatom: LSU rDNA-based phylogenetic differentiation in Skeletonema marinoi/dohrnii (Bacillariophyceae) is not reflected in morphology. Phycologia 2008, 47, 156-167.

(13) Sarno, D.; Kooistra, W. H. C. F.; Medlin, L. K.; Percopo, I.; Zingone, A. Diversity in the Genusskeletonema (Bacillariophyceae). II. An assessment of the taxonomy of $S$. costatum-Like Species with the Description of Four New Species. J. Phycol. 2005, 41, 151-176.

(14) Walsh, G. E.; Alexander, S. V. A Marine Algal Bioassay Method: Results with Pesticides and Industrial Wastes. Water, Air, Soil Pollut. 1980, 13, 45-55.

(15) Stanton, M. R. Baseline laboratory studies of sphalerite ( $\mathrm{ZnS}$ ) dissolution: Effects on aqueous metal concentrations and solubilization rates. In National Meeting of the American Society of Mining and Reclamation; American Society of Mining and Reclamation, 2005; pp $1155-1165$.

(16) Cook, N. J.; Ciobanu, C. L.; Pring, A.; Skinner, W.; Shimizu, M.; Danyushevsky, L.; Saini-Eidukat, B.; Melcher, F. Trace and minor elements in sphalerite: A LA-ICPMS study. Geochim. Cosmochim. Acta 2009, 73, 4761-4791.

(17) Tsang, J. J.; Parry, D. L. Metal mobilization from complex sulfide ore concentrate: Effect of light and pH. Aust. J. Chem. 2004, 57, 971-978.

(18) Feely, R. A.; Lewison, M.; Massoth, G. J.; Robert-Baldo, G.; Lavelle, J. W.; Byrne, R. H.; Von Damm, K. L.; Curl, H. C. Composition and Dissolution of Black Smoker Particulates from Active Vents on the Juan de Fuca Ridge. J. Geophys. Res., [Solid Earth Planets] 1987, 92, 11347-11363.

(19) Herzig, P. M.; Hannington, M. D. Polymetallic massive sulfides at the modern seafloor a review. Ore Geol. Rev. 1995, 10, 95-115.

(20) Kandpal, G.; Srivastava, P. C.; Ram, B. Kinetics of desorption of heavy metals from polluted soils: Influence of soil type and metal source. Water, Air, Soil Pollut. 2005, 161, 353-363.

(21) Backes, E. A.; Mclaren, R. G.; Rate, A. W.; Swift, R. S. Kinetics of cadmium and cobalt desorption from iron and manganese oxides. Soil Sci. Soc. Am. J. 1995, 59, 778-785.

(22) Jean, G. E.; Bancroft, G. M. Heavy metal adsorption by sulphide mineral surfaces. Geochim. Cosmochim. Acta 1986, 50, 1455-1463.

(23) Feng, X. H.; Zhai, L. M.; Tan, W. F.; Liu, F.; He, J. Z. Adsorption and redox reactions of heavy metals on synthesized Mn oxide minerals. Environ. Pollut. 2007, 147, 366-373.

(24) Ni, S.; Ju, Y.; Hou, Q.; Wang, S.; Liu, Q.; Wu, Y.; Xiao, L. Enrichment of heavy metal elements and their adsorption on iron oxides during carbonate rock weathering process. Prog. Nat. Sci. 2009, 19, 1133-1139.

(25) Sun, Z.; Forsling, W.; Rönngren, L.; Sjöberg, S. Surface reactions in aqueous metal sulfide systems. 1 . Fundamental surface reactions of hydrous $\mathrm{PbS}$ and $\mathrm{ZnS}$. Int. J. Miner. Process. 1991, 33, 83-93.

(26) Rönngren, L.; Sjöberg, S.; Sun, Z.-X.; Forsling, W. Surface reactions in aqueous metal sulfide systems: 5 . The complexation of sulfide ions at the $\mathrm{ZnS}-\mathrm{H}_{2} \mathrm{O}$ and $\mathrm{PbS}-\mathrm{H}_{2} \mathrm{O}$ interfaces. J. Colloid Interface Sci. 1994, 162, 227-235.

(27) Walsh, G. E.; McLaughlin, L. L.; Yoder, M. J.; Moody, P. H.; Lores, E. M.; Forester, J.; Wessinger-Duvall, P. B. Minutocellus Polymorphus: A new marine diatom for use in algal toxicity test. Environ. Toxicol. Chem. 1988, 7, 925-929.

(28) Ward, T. J.; Boeri, R. L. Acute Static Toxicity of Nonylphenol to the Marine Alga Skeletonema costatum; EnviroSystems Study No. 8970CMA; EnviroSystems Division, Resource Analysts, Inc.: Hampton, $\mathrm{NH}, 1990$.
(29) Sanders, J. G. Effects of Arsenic Speciation and Phosphate Concentration on Arsenic Inhibition of Skeletonema costatum (Bacillariophyceae). J. Phycol. 1979, 15, 424-428.

(30) USEPA. In Depth Studies on Health and Environmental Impacts of Selected Water Pollutants; Contract No. 68-01-4646, 1978.

(31) Taraldsvik, M.; Myklestad, S. The effect of $\mathrm{pH}$ on growth rate, biochemical composition and extracellular carbohydrate production of the marine diatom Skeletonema costatum. Eur. J. Phycol. 2000, 35, 189-194.

(32) Hageman, P. L.; Seal, R. R.; Diehl, S. F.; Piatak, N. M.; Lowers, H. A. Evaluation of selected static methods used to estimate element mobility, acid-generating and acid-neutralizing potentials associated with geologically diverse mining wastes. Appl. Geochem. 2015, 57, 125-139.

(33) Cappuyns, V.; Swennen, R. The Use of Leaching Tests to Study the Potential Mobilization of Heavy Metals from Soils and Sediments: A Comparison. Water, Air, Soil Pollut. 2008, 191, 95-111.

(34) Collins, P. C.; Croot, P.; Carlsson, J.; Colaço, A.; Grehan, A.; Hyeong, K.; Kennedy, R.; Mohn, C.; Smith, S.; Yamamoto, H.; Rowden, A. A primer for the Environmental Impact Assessment of mining at seafloor massive sulfide deposits. Mar. Pol. 2013, 42, 198209.

(35) Levin, L. A.; Mengerink, K.; Gjerde, K. M.; Rowden, A. A.; Van Dover, C. L.; Clark, M. R.; Ramirez-Llodra, E.; Currie, B.; Smith, C. R.; Sato, K. N.; Gallo, N.; Sweetman, A. K.; Lily, H.; Armstrong, C. W.; Brider, J. Defining "serious harm" to the marine environment in the context of deep-seabed mining. Mar. Pol. 2016, 74, 245-259.

(36) Narita, T.; Oshika, J.; Okamoto, N.; Toyohara, T.; Miwa, T. Summary of environmental impact assessment for mining seafloor massive sulfides in Japan. J. Shipp. Ocean Eng. 2015, 5, 103-114.

(37) Sakai, H.; Gamo, T.; Kim, E.-S.; Tsutsumi, M.; Tanaka, T.; Ishibashi, J.; Wakita, H.; Yamano, M.; Oomori, T. Venting of Carbon Dioxide-Rich Fluid and Hydrate Formation in Mid-Okinawa Trough Backarc Basin. Science 1990, 248, 1093-1096.

(38) Momma, H.; Iwase, R.; Mitsuzawa, K.; Kaiko, Y.; Aoki, M. Deep tow survey in Nanseishoto Region (K95-07-NSS). JAMSTEC J. Deep Sea Res. 1996, 12, 195-210.

(39) Kawagucci, S.; Shirai, K.; Lan, T. F.; Takahata, N.; Tsunogai, U.; Sano, Y.; Gamo, T. Gas geochemical characteristics of hydrothermal plumes at the HAKUREI and JADE vent site, the Izena Cauldron, Okinawa Trough. Geochem. J. 2010, 44, 507-518.

(40) Kawagucci, S.; Miyazaki, J.; Nakajima, R.; Nozaki, T.; Takaya, Y.; Kato, Y.; Shibuya, T.; Konno, U.; Nakaguchi, Y.; Hatada, K.; Hirayama, H.; Fujikura, K.; Furushima, Y.; Yamamoto, H.; Watsuji, T.o.; Ishibashi, J.-i.; Takai, K. Post-drilling changes in fluid discharge pattern, mineral deposition, and fluid chemistry in the Iheya North hydrothermal field, Okinawa Trough. Geochem., Geophys., Geosyst. 2013, 14, 4774-4790.

(41) Dekov, V. M.; Egueh, N. M.; Kamenov, G. D.; Bayon, G.; Lalonde, S. V.; Schmidt, M.; Liebetrau, V.; Munnik, F.; Fouquet, Y.; Tanimizu, M.; Awaleh, M. O.; Guirreh, I.; Le Gall, B. Hydrothermal carbonate chimneys from a continental rift (Afar Rift): Mineralogy, geochemistry, and mode of formation. Chem. Geol. 2014, 387, 87-100.

(42) Nozaki, T.; Ishibashi, J.-I.; Shimada, K.; Nagase, T.; Takaya, Y.; Kato, Y.; Kawagucci, S.; Watsuji, T.; Shibuya, T.; Yamada, R.; Saruhashi, T.; Kyo, M.; Takai, K. Rapid growth of mineral deposits at artificial seafloor hydrothermal vents. Sci. Rep. 2016, 6, 22163.

(43) Truzzi, C.; Illuminati, S.; Finale, C.; Annibaldi, A.; Lestingi, C.; Scarponi, G. Microwave-assisted solvent extraction of melamine from seafood and determination by gas chromatography-mass spectrometry: Optimization by factorial design. Anal. Lett. 2014, 47, 11181133. 